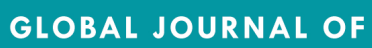 \\ Community Psychology Practice
}

\section{PROMOTING COMMUNITY PRACTICE FOR SOCIAL BENEFIT}

\section{Fostering Critical Thinking about Climate Change: Applying Community Psychology to an Environmental Education Project with Youth}

Livia D. Dittmer and Manuel Riemer Wilfrid Laurier University

Author Note: Livia D. Dittmer, Psychology Department, Wilfrid Laurier University; Manuel Riemer, Psychology Department, Wilfrid Laurier University.

Correspondence concerning this article should be addressed to Livia D. Dittmer, Psychology Department, Wilfrid Laurier University, Waterloo, Ontario, N2L 3C5. E-mail: livia.d.dittmer@gmail.com.

Recommended citation: Dittmer, L.D., \& Riemer, M. (2012). Fostering Critical Thinking about Climate Change: Applying Community Psychology to an Environmental Education Project with Youth. Global Journal of Community Psychology Practice, 3(x), 1-9. Retrieved Day/Month/Year, from (http://www.gjcpp.org/). 


\title{
Fostering Critical Thinking about Climate Change: Applying Community Psychology to an Environmental Education Project with Youth
}

\begin{abstract}
This article argues for the participation of community psychology in issues of global climate change. The knowledge accumulated and experience gained in the discipline of community psychology have great relevance to many topics related to the environment. Practitioners of community psychology could therefore make significant contributions to climate change mitigation. To illustrate this assertion, we describe an education project conducted with youth engaged in a community-based environmental organization. This initiative was motivated by the idea that engaged and critically aware youth often become change agents for social movements. Towards this purpose, rather than using mass marketing strategies to motivate small behavior changes, this project focused intensively on a few youth with the vision that these youth would also influence those around them to rethink their environmental habits. This project was influenced by five community psychology concepts: stakeholder participation, ecological and systems thinking, social justice, praxis, and empirical grounding. In this article we discuss the influence of these concepts on the project's outcomes, as measured through an evaluative study conducted to assess the impacts of the project on the participating youth in terms of their thinking and action. The contributions of community psychology were found to have greatly impacted the quality of the project and the outcomes experienced by the youth.
\end{abstract}

Keywords: global climate change, environment, youth, education, community psychology

Over its years of existence, community psychology has taken on increasingly diverse social issues for research and intervention. As the world advances in complexity and new problems emerge, it is important that our discipline continues to be responsive to the needs of humanity through our selection of priorities for research and intervention. Global climate change and the need for a shift toward a culture of environmental sustainability have been identified by several authors as prospective priority areas for community psychology (e.g., Culley \& Angelique, 2010; Riemer, 2010; Riemer \& Reich, 2011; Quimby $\&$ Angelique, 2011). Community psychology has the potential to play an important leadership role in developing mitigation strategies that are based on ecological and systems thinking and appropriately reflect the complexity of the environmental situation that the world faces today.

In reflecting on existing efforts to address these environmental issues, we are reminded of Einstein's often quoted insight that the problems that exist in the world today cannot be solved by the level of thinking that created them. Many psychology-informed behavior change strategies, for example, seem to accept financial and social status elements as essential to motivating individuals to make environmental choices, rather than challenging individuals in order to seek more complex methods of change that target other forms of motivation more likely to make significant impact (World Wildlife Fund [WWF], 2008). We agree with other authors (e.g., Clover, 2002; Harré, 2011; Riemer, 2010; WWF, 2008) that an alternative approach is needed, one that reflects a more complex method of individual and social transformation. In this paper, we present an example of how community psychology theory and principles can be used to create an environmental change program that reflects complex systems thinking through the mode of education.

\footnotetext{
Mainstream psychology has focused much of its research regarding sustainability on the internal drivers of consumption behavior (Uzzell \& Räthel, 2009). Axelrod and Lehman (1993), for example, identify three key factors associated with environmental behaviors: attitudes ("I believe, therefore I act"), sense of efficacy ("I can, therefore I act"), and motivation ("I desire, therefore I act"). These types of frameworks locate impetus for environmental change within individuals. From this orientation, methods are developed that apply marketing techniques, such as market segmentation and financial incentives, to motivate individuals to make small and painless life changes that are in line with society's vision of green consumption (WWF, 2008).
} 


\section{Global Journal of Community Psychology Practice}

The assumption on which this strategy is based is that individuals choose to make change (or not to make change) based on what they think will maximize their personal benefit (Wilson \& Dowlatabadi, 2007). This vision of human nature, however, fails to take into account the embeddedness of individuals in social, cultural, and political contexts (Uzzell \& Räthel, 2009); the inclusive elements of self-identity that help individuals identify with external factors such as other people and nature (WWF, 2008); and individuals' capacity to make sacrifices for the collective (Nelson \& Prilleltensky, 2005).

Furthermore, the foot-in-the-door assumption, upon which these efforts are based, is that these simple changes must be the first priority before larger behavior changes can be encouraged: "...most of our consumer research points to the need for proenvironmental behaviors to fit within one's current lifestyle, even if one might aim for more fundamental shifts over the longer term" (Department for Environment, Food, and Rural Affairs [DEFRA], 2007). Observation of this strategy over the years of its use, however, have led to the conclusion that these small changes of specific behaviors, in actuality, "may serve to defer, or even undermine, prospects for the more far-reaching and systemic behavioral changes that are needed" (WWF, 2008, p. 5). Thus, these changes are ameliorative at best but certainly not transformative, and therefore fall short of the level of change that is needed to mitigate climatic catastrophe (IPCC, 2007).

The World Wildlife Fund (2008) suggests that for transformative change to occur, the underlying assumptions of materialism and individualism must be challenged. They propose that, in place of these assumptions, the ability to value others when making behavioral choices should be prioritized. This inclusive aspect of self-identity is undermined by the marketing approach, which encourages people to consider their consumer behaviors to be what define their identity, rather than intrinsic or morally-driven factors. A transformative process that changes this way of thinking would require "a re-examination of the relationships between people, and between people and the natural environment" (WWF, 2008, p. 8) in order to create a systemic approach to environmental involvement that reflects inclusive values.

Such an expanded vision would allow for the creation of a system better able to account for the heterogeneous mix of individuals' attitudes and motivations regarding environmental choices (Wilson \& Dowlatabadi, 2007) and the complexity of the human dimensions of climate change (Hossay, 2006; Oskamp, 2000; Riemer, 2010; Speth, 2008). In short, what is needed is a shift away from the limitations imposed by the marketing model and its simple approach, toward an approach that takes into account the complexities of the human response to the phenomenon of climate change. Community psychology has a great deal to offer in conceptualizing and realizing this shift. Despite the peripheral attention issues of global climate change have received by community psychology researchers and practitioners, the research interests, theoretical perspectives, and values framework of community psychology provide solid foundations for this focus to emerge (Riemer, 2010; Riemer \& Reich, 2011).

Riemer and Reich (2011) argue that many research topics already of interest to community psychologists are closely linked to global climate change and that, oftentimes, efforts to create transformative change by addressing root causes of other phenomena would naturally lead to environmental factors. They explore immigration as an example of such a research topic, pointing to the connections between an influx of environmental refugees and resulting implications for issues related to sense of community, diversity, and social justice. Efforts for transformative change would look to the root causes of this influx: environmental disasters. These authors also suggest that many theoretical perspectives of community psychology are synchronous with the needs incurred by our changing environment. The application of ecological and systems thinking, for example, is an area of strength in community psychology and would contribute a great deal to the analysis of environmental impacts on individuals, groups, and communities.

Riemer (2010) also highlights four values of community psychology, as identified by Nelson and Prilleltensky (2010), that could motivate community psychologists to care about environmental issues: the concern for individual, relational, and collective wellbeing; the fight for social justice; the efforts to address issues of power and oppression; and the prevention of conflict and violence. However, despite this clear interconnectedness, the available literature of our field lacks examples of applying community psychology principles, theories, and methods to environmental initiatives (Riemer \& Reich, 2011). By presenting an example of an environmental action project informed by community psychology we hope to help fill this gap.

\section{Critical Consciousness Workshops for Youth}

This section explores the application of community psychology concepts and approaches to an initiative aimed at engaging youth in environmental action through consciousness raising and capacity building. This initiative was motivated by the idea that engaged 


\section{Global Journal of Community Psychology Practice}

and critically aware youth often become change agents for social movements, including movements that work toward the cultural shift that is needed to deal with global climate change (Karan, 1994; Quiroz-Martinez, Wu, \& Zimmerman, 2005; Youniss et al., 2002). Towards this purpose, rather than using mass marketing strategies to motivate small behavior changes, this project focused intensively on a few youth with the vision that these youth would also influence those around them to rethink their environmental habits. In this section, we describe the intervention setting and the pilot research that preceded the main project, the main project goals, the research methods, and some of the project outcomes. Throughout this section we make explicit the community psychology influences on this project.

\section{The Main Project}

\section{Intervention Setting and Pilot Research}

Reduce the Juice (RTJ) is a community-based, youthfocused, environmental organization currently based in Waterloo Region in southwestern Ontario. It was initiated in 2005 as a youth-led organization, with the goal of contributing to climate change mitigation by engaging young people as agents of change. Through summer projects, for which the organization hires several high school-aged youth to conduct community outreach, RTJ has two primary goals: (a) to educate residents about environmental issues and motivate them to alter their environment-related behaviors, and (b) to empower youth to become community leaders and role models in creating a culture of conservation. They also work with high school teams on projects related to renewable energy during the school term. For example, a student group built a solar-powered vehicle with the help of engineering students from a local university. RTJ is funded primarily through small project-based grants from different funding agencies and by partnering with local government organizations such as Public Health or Waste Management.

Our research team has worked with RTJ since 2008 in several ways. First, we partnered in conducting a post-hoc evaluation of their regular summer program, which they had offered since 2005 . This was partially done as a case study in a community psychology methodology course for which the second author (Manuel) was the instructor and the first author (Livia) a student. This evaluation included interviews with the RTJ's high school students and a survey with residents targeted by the students (this was our pilot research). Through the interviews, it became evident that the students recognized the limitations of focusing on residents' environmental behaviors without also considering other systemic levels that affect those behaviors (e.g., urban planning; Riemer, Dittmer, \& Klein, 2009). Because of this finding, we proposed to the organization that this limitation could be addressed by creating spaces for the youth to learn about and discuss these other levels. Together, the RTJ Team Leaders and our research team developed a workshop series that would draw heavily on insights and tools from community psychology to raise consciousness about global climate change at multiple levels of analysis and build capacity for greater involvement in environmental issues. This project was implemented by RTJ during their 2009 summer program. In order to learn about the effectiveness of these workshops from this specific case, we collected data from several sources (see below).

In the summer of 2010 RTJ repeated the workshop series with slight modifications but we did not collect additional data. One change in 2010 was the inclusion of a live video exchange with students in India who participated in a similar series of workshops. The partnership between RTJ and our research group and our joined learning and development has led to an ongoing, large, multinational, longitudinal study, "Youth Leading Environmental Change," which investigates the effectiveness of an environmental justice workshop for university students. The workshop consists of 10 two-hour topical modules and two live video exchanges. In this paper, however, we present what we learned from developing the original workshop series in 2009 and from the evaluative data we collected at that time.

As described above, we designed the workshops to fill a gap in RTJ's largely individual-focused mode of operation by expanding the youths' vision to include the multiple levels (government, businesses, peer groups, etc.) that influence environmental behaviors and the connections between these levels. The second component of the workshops' message was that the forces that influence individuals can in turn be affected by the individuals themselves. This aspect sought to raise, through a process of critical reflection and discussion, the youths' consciousness of the influence they can have on the multifarious forces that impact the environmental situation.

The workshops were designed and implemented in partnership between the researchers and the RTJ Team Leaders. This involved four steps: (a) an initial meeting to select the themes and develop content for each workshop, (b) preparatory meetings approximately two days before each workshop to clarify plans and establish facilitation roles for each portion of the session, (c) co-facilitation of the 


\section{Global Journal of Community Psychology Practice}

workshops, and (d) meeting after each workshop to reflect and document our learning. The final step sometimes only involved the researchers because of time constraints, but the Team Leaders would reflect independently through regular journal entries.

Each workshop was two to three hours long and focused on a contextual theme related to the issue of climate change. The themes were designed to increase in complexity over the summer and to build on each other conceptually. All four workshops involved five components: reflection on the previous workshop and recent RTJ field work, introduction to the theme to be addressed, presentation of media related to the theme, discussion of the media and related ideas, and action planning. Guest participation in discussions and interactive learning activities were also included.

\section{Workshop Themes}

Workshop 1: Consumerism. Using consumer culture and its impact on the environment as an example, the first workshop provided an introduction to the purpose of the workshops and an orientation to the main tool to be used for critical consciousness raising: the ecological model (Dalton, Elias, \& Wandersman, 2002; Kelly, Ryan, Altman, \& Stelzner, 2000). This model provided the youth with a conceptual framework and a common language to explore and discuss the complex interconnections between individuals' behaviors and systemic influences at multiple levels of analysis.

Workshop 2: Urban planning and design. This workshop addressed an issue that was commonly encountered by the youth in their interactions with residents: urban planning and design. The discussion included a focus on such factors as bike lanes and suburban sprawl, which were very relevant to RTJ's focus on promoting the use of non- or low-polluting modes of transportation.

Workshop 3: Government and policy. The third workshop took a step away from residents' proximal concerns to address the relationship between government policy and climate change. The content focused on the process by which legislation is developed and how individuals and groups can influence this process. The Green Energy Act of Ontario was explored to provide an example of these ideas in the context of the environment.

Workshop 4: Environmental justice. The fourth and final workshop addressed the issue of environmental injustice: how those with the least power to create change in the environment are often the ones most impacted by its effects (Hossay, 2006). This issue, which was quite distal from the youths' everyday lives, was important to include because of the fact that these youth were all members of a privileged group and it is important for members of privileged groups to develop consciousness of their influence over issues that impact others' lives (Goodman, 2001). By critically examining and discussing examples of environmental injustice, this workshop was designed to help the youth understand the different actors and forces that sustain environmental injustice, and to begin to explore the role they could play in building a more just system.

\section{Workshop Components}

Reflections on RTJ field work. At the beginning of each workshop, the youth were asked to reflect on their fieldwork over the days since the previous workshop. This included reflection on how their experiences in the field related to the things they had learned in the workshops, following the principles of community-service learning (Honnet \& Poulsen, 1989; Jacoby \& Associates, 1996).

Media presentations. As a component of each workshop, a video or slideshow presentation was used to stimulate group discussions.

Topical group discussions. The main component of the workshops were the youths' discussions, which were focused on the theme of each workshop and provided space for in-depth exploration of the topic and its potential integration into conversations with residents. In these guided discussions the youth were encouraged to use the ecological model to anchor their thoughts in systems thinking.

Co-facilitation approach. Through their partnership, the researchers and the RTJ Team Leaders provided structure and guidance for the workshop discussions, as well as contributing supplemental information and insights when helpful.

Interactive activities. Interactive activities consisted of the ecological model discussion in workshops one, two, and three; a Green Energy Act scavenger hunt in workshop three; and a guest presenter in workshop four.

Action planning. The final component of the last three workshops was approximately 30 to 45 minutes dedicated to planning for an action project to be carried out by the youth. The youth first decided together what action they wanted to take and then developed an action plan. The intention for the action project was for the youth to target something located on an ecological level beyond the individual (e.g., the community level). 


\section{Global Journal of Community Psychology Practice}

\section{Community Psychology Influences}

In designing and implementing this project, we, as community psychology scholars, drew heavily from community psychology theory and principles of practice. In this section, we discuss five community psychology concepts that particularly influenced this project: stakeholder participation, ecological and systems thinking, social justice, praxis, and empirical grounding.

Stakeholder participation. Because this project had direct implications for the functioning of RTJ and the achievement of its mandate, we considered it to be important that members of the organization be involved as much as possible in planning and implementing the workshops. Indeed, one of the goals of the project was to contribute to the advancement of the organization itself by building skills and knowledge in Team Leaders to provide a broader scope of training to the organization's youth employees. This is in keeping with community psychology's conceptualization of power sharing in that through this partnership we sought to create opportunities and build capacity - two central features of power (Nelson \& Prilleltensky, 2010) - of the Team Leaders to strengthen their organization and for the research team to implement an effective study of the project (described further below). The latter goal was supported through stakeholder participation by providing insight into the functioning of RTJ and access to the strengths of the organization, gained through its experience working with youth.

Ecological and systems thinking. From a community psychology perspective, the purpose of the ecological metaphor is synchronous with the goals of the workshops: to build understanding about individuals within their contexts and to attempt to "change those aspects of the community that pollute the possibilities for local citizens to control their own lives and improve their community" (Trickett, 2009, p. 396). The visual representation of multiple ecological layers (e.g., as depicted in Dalton, Elias, \& Wandersman, 2007, p. 18), was intended to facilitate the youths' understanding of the complexity of primary and secondary causes of global climate change and increase knowledge about how strategies to address these causes need to consider this complexity. We used recycling as an example to demonstrate how our actions are influenced by family members, neighbours, city regulations and services, business practices, cultural values, etc. Being able to map these multiple influences on a visual model, made this complexity less overwhelming. The ecological model and related systems thinking also influenced the way we selected the themes for this workshop series; we intentionally selected topics that related to multiple layers in the ecological model, including those that seemed far removed from individuals' behaviors.

Social justice. An injustice inherent in the development of global climate change is that those countries that have contributed most to the problem are least affected by its negative impacts and vice versa (Hossay, 2006). The participants of the workshops were all members of a privileged group that benefits from the production of green house gases (e.g., through increased personal comfort) without having to face the consequences of that production (at least not in the immediate future). Jost and Major (2001) discuss how the different life circumstances of people who are relatively privileged compare to those who are disadvantaged, which often results in advantaged people being oblivious of the challenges faced by others. By focusing on what Nelson and Prilleltensky (2010) describe as fair and equitable allocation of obligations in society, the workshops were intended to help the youth explore their role in contributing to environmental justice.

Praxis. In community psychology practice, praxis refers to the connections between theory and action (e.g., Montero, 2008; Partridge, 2008; Prilleltensky, 2001). Critical reflection on one's actions using theoretical frameworks such as the ecological model ensures informed practice that has the potential for transformative change. This idea was applied extensively in the workshops; not only was there time dedicated in each workshop to reflect on how the concepts discussed in the previous workshop had been applied in their conversations with residents in the field, but the students also designed and began to carry out an action project during the workshop sessions. Discussions were framed within this context of action and reflection in relation to the theory of each workshop topic.

Empirical grounding. As a scientific discipline, community psychology values strong empirical foundations for interventions and research (Dalton, Elias, \& Wandersman, 2007). The design of these workshops and the research plan were based on existing knowledge about youth engagement (Riemer \& Lynes, 2011) and on previous pilot research with RTJ (Dittmer, Wicks, \& Riemer, 2009; Riemer, Dittmer, \& Klein, 2009; Riemer et al., 2009; Riemer $\&$ Patterson, 2009). The current workshop series was evaluated as well, which we present in the next section. 


\section{Global Journal of Community Psychology Practice}

\section{Evaluation of the Workshops}

In this section we provide a brief overview of the evaluation conducted to assess the effectiveness of this project, including a summary of the methods, a description of the main relevant findings, and a short discussion.

\section{Methods}

Through a single case, holistic case study (Yin, 2009), using variety of data sources, we worked with the two Team Leaders to collect data that would contribute to our understanding of the five youth participants' experience in the workshops and the impacts of the project on their thinking and action. The two Team Leaders were university students who were hired by RTJ to train the youth and accompany them in the field to visit local residents. In the summer of 2009, RTJ hired five high school aged youth to work as student campaigners in their community outreach education program; all five of these students participated in the workshops and the related research. Three were men and two were women. They ranged in age from 17 to 19 . The students were recruited from a local high school.

Several forms of data were gathered for the purposes of this evaluation. Data were collected during the workshop sessions, which were audio recorded; through follow-up, semi-structured interviews with each participant four to six months after the last workshop; through journals kept by the Team Leaders, who shared their reflections on the youths' participation and their experiences in the field; through field observations, made by the first author, of the youth doing their community outreach; and, finally, through pre and post questionnaires completed by the youth, which assessed their general knowledge of environmental and social issues, their interactions with parents and peers in regard to various social issues (the Parent and Peers Interaction scales; Pancer, Pratt, Hunsberger, \& Alisat, 2007), and their previous involvement in various community service activities (the Youth Inventory of Involvement; Pancer et al., 2007). By collecting data from three perspectives (the youth, the Team Leaders, and the researchers), we sought to identify themes that would represent the key processes and outcomes of the workshops. The Research Ethics Board of Wilfrid Laurier University approved the study procedures.

\section{Key Findings - Critical Thinking}

Connected to the use of the ecological model as a tool for the workshop discussions, indicators of heightened critical consciousness were determined, for the purposes of this evaluation, to be expressions of critical thinking at systems levels beyond the individual. Through data analysis, three forms of critical thinking emerged: systems thinking, reflective thinking, and empathic thinking.

Systems thinking. In terms of systems thinking, four of the youth felt that the workshops contributed to their understanding of the complexity of environmental issues, beyond the individual level. For example, Gary (a pseudonym) expressed in his interview the importance of involving community in creating environmental change:

...some of the talk about how it was more useful to have the community do your work for you and have people from within the community working was really valuable to me...that really spoke to me because I've seen a lot of activism sort of stuff fail, I've read about it, because it's just the types of groups trying to impose themselves on it without understanding the local community.

Systems thinking was also evident in the way the youth spoke about how they thought about their interactions with residents in their work with RTJ. As discussed by Paul in his interview:

I mean lots of people in the suburban areas were talking about, you know, flexibility with the buses...way back when we were planning for creating suburbs and stuff like that we weren't really thinking of public transportation as a surely viable option and it shows when you hear the concerns of the people.

During the workshops, the youth identified factors at the level of the individual that influenced their environmental behaviors (e.g., how convenience, habits, and a desire for privacy affect people's transportation choices) as well as certain factors at higher levels such as the presence of bike paths and accessible bus routes. With further guidance from the facilitators and feedback from each other, they were also able to identify more abstract forms of higherlevel factors, such as social norms, family rituals, and the influence of economics. The interactions between the individual and other ecological levels were also identified by the youth, acknowledging that higher levels (e.g., media) affect individual levels (e.g., sense of social status). The impact of the workshops on the youths' thinking about systems levels was also noted by one of the Team Leaders in her journal, particularly the impact of this learning on conversations with residents:

...it was definitely an eye opener [for the youth] into why certain issues are happening... When getting pledges and surveys the students end up 


\section{Global Journal of Community Psychology Practice}

spending more time with the residents, and when I ask them why they took so long, it's because the students actually get into really good conversations with the residents about issues that I think the students are more knowledgeable on and more comfortable talking about now that they have been able to look at barriers and influences to certain issues, such as the [transit system] and biking lanes.

Awareness of the systemic levels that affect individuals' environmental behaviors stands in contrast to the exclusive focus on individual-level influences that was evidenced through the pilot research.

Reflective thinking. Three of the youth expressed reflective critical thinking in the context of conceptualizing environmental issues on higher systems levels during their interviews. Alice, for example, reflected on the challenges of creating effective projects based on the experience of the group during their action project: “...it brought up some of the problems in actually implementing programs and logistics and stuff like that that a lot of people probably overlook when they're initially planning something in their optimism." Also, Paul provided an example of how the media component of the workshops caused him to become more conscious of how he thinks about the other media he is exposed to related to environmental issues: "I know not to believe everything I hear even, you know, watching the news... I know that being well informed is to have a better sense of what's fact and what they're just pulling out of thin air." One of the Team Leaders described in her journal the importance of the reflection component of the workshops for the longterm impact of the content: "The reflection is really important... making the workshops not a one day event, but something that will hopefully stick with them for years to come." The reflective thinking fostered by the workshops is a further dimension of critical thought that deepens the systems thinking component described above.

Empathic thinking. The third dimension of critical thinking found in the data was empathic thinking, which was discussed by three of the participants in their interviews. This type of consciousness was particularly related to the environmental justice themed workshop during which a media clip was shown that described the situation of an Aboriginal community in Sarnia, Ontario that is being severely impacted by the toxic emissions of local industries. Claire expressed in her interview how learning about this situation of environmental injustice affected her: "I'm more conscious of things that are happening, like this thing in Sarnia too, that made me freak out a bit. I was telling my parents about it, how much there is air pollution, just because of that movie clip." Learning about this situation in Sarnia also affected Gary, who shared in his interview how this new information shaped his understanding of the state of environmental justice in Canada:
...it shaped my perspective on discrimination against Native people in Canada because I guess I'd never really encountered that. I'd seen it as an artifact of the long past, like the pre-60s era...to see it so clearly and effectively documented in Canada was so shocking to me.

The dimension of empathic thinking provides further depth to the youths' capacity for understanding the multiple dimensions and levels of climate change.

\section{Key Findings - Critical Action}

In addition to outcomes related to the participants' thinking about environmental issues as social justice concerns, data also indicated that the workshops influenced the youths' motivation to engage in environmental issues and their relationship with environmental change, both intra and interpersonally.

Motivation. One way in which the youth expressed that they felt motivated following their experience with the workshops was to take initiative to search out further information on their own and to inform others about environmental issues. Seth explained in his interview how the environmental justice workshop motivated him to:

become a bit more involved in certain things... I've been doing more research into the environmental policies of the Canadian government and whatnot and sort of voicing my opinion more in class to try to get people involved in it.

Similar to Seth's actions to become more informed about Canadian environmental policies, Paul shared in his interview how in the future he intends to become an active environmental voter:

I'll definitely start paying attention a lot more than I regularly did... I'm going to try to get informed for voting in the future, you know, looking at their environmental policies is definitely something that I'll start to do a lot more often.

Finally, Claire shared in her interview how having access to further knowledge about environmental issues motivated her to live a more environmental lifestyle: 


\section{Global Journal of Community Psychology Practice}

It sort of really helped. Just like the tiny things, like pumping up your tires and not going through a drive thru... since now I know it's bad for the environment I won't use it...it sort of really helped me in every-day life and I learned a lot about it too.

This motivation to pursue further learning and action following the conclusion of the summer project and into their futures as adult citizens indicates a practical outcome of the workshops for participants'

involvement in environmental issues.

Relationship with environmental issues. The youth expressed that their relationship with environmental issues was altered in terms of their activities, their attitudes, and their plans for their future relationships with the environment. Seth expressed in his interview how, in particular, he has become a more active environmental educator:

I think it's shown me more of an urgency to inform other people. I'd always assumed that people knew sort of the issues with global warming, but I'm starting to learn that a lot of people don't and that's not a good thing.

This heightened engagement with environmental education identifies one dimension of a relationship with environmental issues. A further dimension of a relationship with environmental issues expressed by the youth relates to the capacity for systems thinking. Gary described in his interview how the workshops helped him conceptualize the form of environmental action he hopes to pursue in the future on the community level: “... [the environmental justice workshop] started me thinking on I guess my current train of thought, like I was saying with community gardens, about working with marginalized groups and working from within the community more." Adopting environmental lifestyles by becoming active community workers and educators is a significant outcome of the workshops that has implications, beyond the youth themselves, for their interactions with others and with their communities.

\section{Discussion}

The findings reported in the preceding section provide initial support for the ability of the workshops to raise critical consciousness of the multiple levels at work in issues of global climate change and to contribute to the participants' active and critical engagement in environmental issues. In this section, we discuss the implications of these findings in relation to the community psychology concepts of ecological and systems thinking, social justice, and praxis. See Table I for a summary of the connections between the evaluation's key findings and these three community psychology concepts.

Table I. Summary of Connections between the Evaluation's Key Findings and Three Relevant Community Psychology Concepts

\begin{tabular}{|c|c|c|}
\hline $\begin{array}{c}\text { Community } \\
\text { Psychology } \\
\text { Concept }\end{array}$ & $\begin{array}{l}\text { Evaluation } \\
\text { Findings }\end{array}$ & Key Connections \\
\hline \multirow{3}{*}{$\begin{array}{c}\text { Ecological \& } \\
\text { Systems } \\
\text { Thinking }\end{array}$} & $\begin{array}{c}\text { Critical thinking } \\
\text { (systems) }\end{array}$ & $\begin{array}{l}\text { Youth showed familiarity } \\
\text { with the language and } \\
\text { concepts of the ecological } \\
\text { model and ability to } \\
\text { conceptualize environmental } \\
\text { issues at levels beyond the } \\
\text { individual }\end{array}$ \\
\hline & Motivation & $\begin{array}{l}\text { Youth expressed increased } \\
\text { motivation to engage with } \\
\text { environmental issues at } \\
\text { levels beyond the individual }\end{array}$ \\
\hline & $\begin{array}{l}\text { Relationship } \\
\text { with } \\
\text { environmental } \\
\text { issues }\end{array}$ & $\begin{array}{l}\text { The youth expressed } \\
\text { increased ability to take } \\
\text { environmental action at } \\
\text { levels beyond the individual, } \\
\text { particularly sociopolitical } \\
\text { actions }\end{array}$ \\
\hline \multirow{2}{*}{$\begin{array}{l}\text { Social } \\
\text { Justice }\end{array}$} & $\begin{array}{l}\text { Critical thinking } \\
\text { (empathic) }\end{array}$ & $\begin{array}{l}\text { The youth expressed that } \\
\text { exposure to information } \\
\text { about environmental justice } \\
\text { shaped their thinking about } \\
\text { the injustices faced by others }\end{array}$ \\
\hline & $\begin{array}{l}\text { Relationship } \\
\text { with } \\
\text { environmental } \\
\text { issues }\end{array}$ & $\begin{array}{l}\text { The youth expressed } \\
\text { attitudes, activities, and plans } \\
\text { that were motivated by a } \\
\text { concern for environmental } \\
\text { justice }\end{array}$ \\
\hline \multirow{2}{*}{ Praxis } & $\begin{array}{l}\text { Critical thinking } \\
\text { (reflective, } \\
\text { systems, \& } \\
\text { empathic) }\end{array}$ & $\begin{array}{l}\text { All three forms of critical } \\
\text { thinking were contextualized } \\
\text { within the youths' personal } \\
\text { experiences through } \\
\text { reflection and discussion }\end{array}$ \\
\hline & Motivation & $\begin{array}{l}\text { The youth used reflections on } \\
\text { their own learning to } \\
\text { determine relevant actions } \\
\text { they would be motivated to } \\
\text { take }\end{array}$ \\
\hline
\end{tabular}

Ecological and systems thinking. The community psychology concept of ecological and systems thinking was reflected in the evaluation's findings of critical systems thinking, motivation, and youths' relationship with environmental issues. The use of the ecological model as a theoretical framework, which the youth learned to use with greater facility and complexity over time, seemed to provide useful and effective tools for thinking critically about systems levels beyond the individual. In particular, the youth 


\section{Global Journal of Community Psychology Practice}

showed familiarity with the language and concepts of the ecological model and an ability to conceptualize environmental issues at levels beyond the individual. This indicates that the workshops were effective in helping the youth develop a pattern of critical thinking that fosters their ability to think of issues in terms of their full complexity.

The participants' increased familiarity with ecological levels seemed to influence the types of actions they were motivated to pursue because they reflected greater awareness of types of information and opportunities for action beyond the individual level (e.g., environmental voting behavior, seeking more information about Canadian environmental policy) that the youth had not been sufficiently motivated to pursue previously. This also related to the participants' relationship with environmental issues. Motivation to pursue these types of activities suggested altered attitudes toward engagement in environmental topics; in this case the youth seemed to have developed keener awareness of the political, interpersonal, and community-based dimensions of environmental issues and their potential involvement in them.

Social justice. Because of the framing of environmental issues in terms of social justice, the youth were exposed to information about situations of environmental injustice both globally and locally. Several of the participants discussed the impacts of this information on their thinking about environmental issues. Learning about the situation faced by people in the nearby city of Sarnia (only 200 kilometers/125 miles away from Waterloo) was described by the youth as being particularly powerful in the way it affected their thinking about the reality of environmental justice. Framing the information as a social justice issue connected the students to the issue through an empathic response, such that they felt "shocked" and "freaked out" by the information. This was potentially more impactful than had the concepts been communicated as basic facts or information without the stories that accompanied them. The use of stories has been documented as being an effective tool in education; in terms of social justice and critical thinking, stories have "tremendous potential to engage students in sustained social critique if they are heard and considered" (Enisco, 2011, p. 21). The personal connection with environmental justice experienced by the youth seemed to have influenced their relationship with environmental issues; their attitudes and plans were connected to a sense of "urgency to inform other people" and a desire to engage with marginalized groups in the community.
Praxis. The three components of critical thinking (systems, reflective, and empathic) identified in the data all provide evidence of a system of praxis, in line with Freire's (1970/2008) original conceptualization. The majority of the youths' expressions of systems, reflective, or empathic thought were contextualized within their personal experiences and the discussion opportunities offered by the workshops. Freire's two aspects of praxis, reflection and action, were expressed by the youth in terms of how the opportunities to learn and discuss new issues in the workshops reinforced their action experiences, either within RTJ when interacting with residents, or in their short-term and long-term personal lives when sharing these topics with others. In the short-term, the youth were provided with a cyclical, reinforcing process of reflect-act-reflect since time was provided in each workshop for discussion of how the previous workshop's theme had become relevant in their work experiences. In the long-term, the youths' motivation to do further research on environmental issues and to initiate conversations with others may continue this reflection-action-reflection process as they continue to develop their knowledge and skills. As such, motivation is likely to maintain this system of praxis as the youth engage in further action, reflection, and discussion related to environmental issues.

\section{Conclusions}

The positive outcomes of this project were strongly linked to the contributions made by the concepts employed from community psychology. The five principles and practices integrated into the design and implementation of the education project - stakeholder participation, ecological and systems thinking, social justice, praxis, and empirical grounding - helped produce a high quality education program that impacted the participants' thoughts and behaviors related to environmental issues. The project, guided by these concepts, also contributed to our partner organization, which continued to use the workshop content for training purposes based on the learning gained and capacity built during this project in 2009 . Finally, the process of explicitly linking theoretical concepts of community psychology to the practical work entailed by this project strengthened our conviction that we, as community psychology researchers and practitioners, have access to tools, resources, and knowledge that can make a significant contribution to the environmental movement. Our ability to communicate complex issues in accessible ways, to engage diverse stakeholders in shared visioning, and to conceptualize action with a transformative potential are critical abilities in the search for environmental change strategies that go 


\section{Global Journal of Community Psychology Practice}

beyond simple behavior change. It is our hope that in the future we will see many environmental programs that have been influenced by community psychology.

\section{References}

Axelrod, L. J. \& Lehman, D. R. (1993). Responding to environmental concerns: What factors guide individual action? Journal of Environmental Psychology, 13, 149-159.

Clover, D. (2002). Traversing the gap: Concientización, educative-activism in environmental adult education. Environmental Education Research, 8(3). 315-323.

Culley, M. R. \& Angelique, H. (2011). Participation, power, and the role of community psychology in environmental disputes: A tale of two nuclear cities. American Journal of Community Psychology, 47, 410-426.

Dalton, J. H., Elias, M. J., \& Wandersman, A. (2002). Community psychology: Linking individuals and communities. ( $2^{\text {nd }}$ ed.). Belmont, CA: Thomson Wadsworth.

Department for Environment, Food and Rural Affairs. (2007). A framework for proenvironmental behaviors. Retrieved from www.defra.gov.uk

Dittmer, L. D., Wicks, S., Riemer, M. (2009, April). Evaluation of a community-based approach to environmental conservation and climate change mitigation. Paper presented at the Ontario Ecology and Ethology Colloquium, Kingston, $\mathrm{ON}$.

Enciso, P. (2011). Storytelling in critical literacy pedagogy: Removing the walls between immigrant and non-immigrant youth. English Teaching: Practice and Critique, 10, 21-40.

Freire, P. (2008). Pedagogy of the Oppressed. New York, NY: The Continuum International Publishing Group, Inc.

Goodman, D. J. (2001) Promoting diversity and social justice: Educating people form privileged groups. Thousand Oaks, CA: Sage Publications, Inc.

Harré, N. (2011). Psychology for a Better World. Auckland: Department of Psychology, University of Auckland.

Honnet, E. P. \& Poulsen, S. (1989). Principles of good practice for combining service and learning. Racine, WI: University of Michigan, OCSL Press.

Hossay, P. (2006). Unsustainable: A primer for global environmental and social justice. New York, NY: Zed Books.

Intergovernmental Panel on Climate Change (IPCC, 2007). Summary for policymakers. In Climate change 2007: The physical science basis. Contribution of Working Group I to the Fourth Assessment Report of the Intergovernmental Panel on Climate Change (S. Solomon, D. Qin, M. Manning, Z. Chen, M. Marquis, K. B. Averyt, M. Tignor, \& H. L. Miller, Eds.), New York, NY: Cambridge University Press. (Available at http://www.ipcc-wg2.org/)

Jacoby, B., \& Associates (1996). Service-learning in higher education: Concepts and practices. San Francisco, CA: Jossey-Bass.

Jost, J. T., \& Major, B. (Eds.). (2001). The psychology of legitimacy: Emerging perspectives on ideology, justice, and intergroup relations. Cambridge, UK: Cambridge University Press.

Karan, P. P. (1994). Environmental movements in India. American Geographical Society, 8, 32-41.

Kelly, J. G., Ryan, A. M., Altman, B. E., \&Stelzner, S. P. (2000). Understanding and changing social systems: An ecological view. In J. Rappaport \& E. Seidman (Eds.), Handbook of community psychology (133-159). Dordrecht, Netherlands: Kluwer Academic Publishers.

Montero, M. (2008). An insider's look at the development and current state of community psychology in Latin America. Journal of Community Psychology, 36, 661-674.

Nelson, G., \& Prilleltensky, I. (Eds.). (2005). Community psychology: In pursuit of liberation and well-being. New York, NY: Palgrave Macmillan.

Nelson, G., \& Prilleltensky, I. (Eds.). (2010). Community psychology: In pursuit of liberation and well-being. (2nd ed.). New York, NY: Palgrave Macmillan.

Oskamp, S. (2000). Psychological contributions to achieving an ecologically sustainable future for humanity. Journal of Social Issues, 56, 373-390.

Pancer, S. M., Pratt, M., Hunsberger, B., \& Alisat, S. (2007). Community and political involvement in adolescence: What distinguishes the activists from the uninvolved? Journal of Community Psychology, 35, 741-759. 


\section{Global Journal of Community Psychology Practice}

Partridge, W. L. (2008). Praxis and power. Journal of Community Psychology, 36, 161-172.

Prilleltensky, I. (2001). Value-based praxis in community psychology: Moving toward social justice and social action. American Journal of Community Psychology, 29, 747-778.

Quiroz-Martinez, J., Wu, D. P., \& Zimmerman, K. (2005). ReGeneration: Young people shaping environmental justice. Oakland, CA: Movement Strategy Center.

Riemer, M. (2010). Community psychology, the natural environment, and global climate change. In G. Nelson \& I. Prilleltensky (Eds.), Community psychology: In pursuit of liberation and well-being (2nd Ed.). New York: Palgrave.

Riemer, M., Dittmer, L, Klein, K. (2009). Reduce the Juice: Evaluation of the summer campaign 2008 student interviews. Waterloo, ON: Wilfrid Laurier University.

Riemer, M., Klein, K., Dittmer, L., Wicks, S., Sauren, T., Fairlie, S., Dryburgh, R., \& Patterson, K. (2009, June). Creating environmental change from the bottom up. Poster presented at the Twelfth Biennial Conference of the Society for Community Research and Action, Montclair, NJ.

Riemer, M. \& Lynes, J. (2011). Engaging youth in environmental change: A theoretical perspective. In Riemer, M. (Chair). Engaging young people in political and community activism: Opportunities and challenges. Symposium conducted at the biennial conference of the Society for Community, Research, and Action, Chicago, Illinois. June 15-18, 2011.

Riemer, M. \& Patterson, K. (2009). Reduce the Juice: Resident survey summary of results Waterloo summer campaign 2008. Waterloo, ON: Wilfrid Laurier University.
Riemer, M. \& Reich, S. M. (2011). Community psychology and global climate change: Introduction to the special section. American Journal of Community Psychology, 47, 349-353.

Speth, J. G. (2008). The bridge at the end of the world: Capitalism, the environment, and crossing from crisis to sustainability. New Haven, CT: Yale University Press.

Trickett, E. (2009). Community psychology: Individuals and interventions in community context. Annual Review of Psychology, 60, 395419.

Quimby, C. C. \& Angelique, H. (2011). Identifying barriers and catalysts to fostering proenvironmental behavior: Opportunities and challenges for community psychology. American Journal of Community Psychology, 47, 388-396.

Uzzell, D. \& Räthzel, N. (2009). Transforming environmental psychology. Journal of Environmental Psychology, 29, 340-350.

Wilson, C., Dowlatabadi, H. (2007). Models of decision making and residential energy use. Annual Review of Environment and Resources, 32, 169-203.

World Wildlife Fund. (2008). Weathercocks and signposts: The environment movement at crossroads. Retrieved from http://www.wwf.org.uk/strategiesforchange

Yin, R. K. (2009). Case study research: Design and methods. ( $4^{\text {th }}$ ed.). Thousand Oaks, CA: Sage Publications, Inc.

Youniss, J., Bales, S., Christmas-Best, V., Diversei, M., McLaughlin, M., \& Silbereisen, R. (2002). Youth civic engagement in the twenty-first century. Journal of Research on Adolescence, $12,121-148$. 